\title{
Further studies of penicillin resistant gonococci
}

\author{
R. LYNN, C. S. NICOL, M. RIDLEY, D. RIMMER, M. A. E. SYMONDS \\ AND C. WARREN
}

St Thomas's Hospital, London

During the last 10 years a continuing watch has been kept on relative resistance to penicillin among gonococcal strains isolated from patients attending the Venereal Disease Department of St. Thomas' Hospital, London. In our last report (Nicol, Ridley, and Symonds, 1968) it was shown that no less than 37 per cent. of gonococci isolated from male patients during 1966 were partially resistant. Furthermore, increasing the amount of a single dose of procaine penicillin from 300,000 to 600,000 units as recommended by Letchner and Nicol (1961) was still followed by a relapse rate of 14.3 per cent. in the 1966 survey.

This report concerns a similar survey carried out from July to December, 1968.

\section{Material and methods}

CLINICAL

Between August and November, 1968, 103 cultures yielding gonococci were obtained from 103 consecutive male patients in whom a diagnosis of gonococcal urethritis had been made by examination of stained smears.

As before, the diagnosis, treatment, and assessment of these patients was carried out by the staff of the Venereal Disease Department. Initial diagnosis was made on the finding of Gram-negative diplococci in urethral smears made in the clinic. Treatment consisted of a single dose of 2.5 mega units of a mixed penicillin (Triplopen, Glaxo) As previously the clinic staff and the bacteriologists did not compare data until the end of the trial.

\section{BACTERIOLOGICAL}

Differing in method from the previous surveys, the specimen was taken from the patient's urethra with a wire loop and inoculated directly onto a warm culture plate. These plates were collected from the clinic as soon after inoculation as possible.

As one of the ultimate aims of the study is to define an alternative to penicillin for the treatment of gonorrhoea, blood agar plates containing lysed horse blood were used so that sulphonamide and trimethoprim sensitivities could be tested in addition to several antibiotics. It was found that this medium consisting of Oxoid Blood Agar Base 2, plus 10 per cent. lysed horse blood gave a far better

Received for publication September 18, 1969 growth of Neisseria gonorrhoeae than either hydrocoele or chocolate agar which are commonly employed. It was, therefore, used routinely throughout for isolation, subculture, and antibiotic sensitivity testing.

Neisseria gonorrhoeae was identified by standard sugar fermentation reactions. The minimum inhibitory concentrations for penicillin (and a number of other antibacterial agents the results of which will be reported later) were determined by making doubling dilutions of the antibiotics in lysed horse blood medium: the plates were inoculated with a multiple inoculating device delivering approximately $0.03 \mathrm{ml}$. of an overnight growth of each strain made in lysed horse blood broth. All culture plates were incubated at $37^{\circ} \mathrm{C}$. in candle tins. The Oxford staphylococcus and a standard resistant strain of gonococcus were included with each batch of strains tested.

\section{Results}

\section{CLINICAL RESULTS}

In 97 patients the initial gonococcal urethritis was treated routinely as described. Six other patients were treated with a different drug for various reasons such as penicillin sensitivity or the presence of a genital lesion suspected of being syphilitic. 97 patients are classified by age, race, and source of infection in Table I.

TABLE I Classification of patients by age, race, and source of infection

\begin{tabular}{|c|c|c|}
\hline \multicolumn{2}{|l|}{ Classification } & \multirow{2}{*}{ 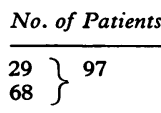 } \\
\hline Age (yrs) & $\begin{array}{l}\text { Under } 24 \\
24 \text { and over }\end{array}$ & \\
\hline Race & $\begin{array}{l}\text { White } \\
\text { Negro } \\
\text { Other }\end{array}$ & $\left.\begin{array}{l}40 \\
42 \\
15\end{array}\right\} 97$ \\
\hline Source of infection & $\begin{array}{l}\text { Heterosexual } \\
\text { Homosexual }\end{array}$ & $\left.\begin{array}{l}83 \\
14\end{array}\right\}^{97}$ \\
\hline
\end{tabular}

Table II (opposite) gives details of those who needed retreatment. Their subdivision into relapsed or re-infected cases again follows the criterion of Evans (1966), e.g. if the gonococci reappear within 14 days of treatment and if further sexual intercourse is denied 
by the patient then a relapse is presumed. There were six relapses and six re-infections.

TABLE II Post-treatment gonorrhoea (relapses and re-infections)

\begin{tabular}{|c|c|c|}
\hline \multicolumn{2}{|l|}{ Patients } & \multirow{2}{*}{$\begin{array}{l}\text { Percentage of those } \\
\text { treated } \\
100\end{array}$} \\
\hline Number treated & 97 & \\
\hline $\begin{array}{l}\text { Relapses } \\
\text { Re-infections }\end{array}$ & $\begin{array}{l}6 \\
6\end{array}$ & $\begin{array}{l}6 \cdot 2 \\
6 \cdot 2\end{array}$ \\
\hline $\begin{array}{l}\text { Total post-treatment } \\
\text { gonorrhoea }\end{array}$ & 12 & $12 \cdot 4$ \\
\hline
\end{tabular}

BACTERIOLOGICAL RESULTS

The minimum inhibitory concentrations of benzylpenicillin for these 97 strains are shown in Table III. The percentage showing relative resistance is $35 \cdot 1$ per cent. compared with the very similar figure of 37.3 per cent. in 1966.

The degree of correlation between cases classified as relapses rather than re-infections and the presence of strains relatively resistant to penicillin is not as great as in the previous survey. However, the number of patients in these categories is much smaller and there are many other variables.

\section{Discussion}

The total number of cases of post-treatment gonorrhoea (12) is much smaller than the 22 reported in the 1966 survey of a very similar number and group of patients. Indeed, the relapse rate $(6 \cdot 2$ per cent.) appears to have been halved by the use of this larger dose of penicillin. In spite of the high cure rate with this dose, it may well be advisable as a matter of policy to use another drug in future. After a lapse of time it might be hoped that a smaller dose of penicillin would again become effective in the cure of gonorrhoea.

Testing of such other antibacterial agents in vitro combined with clinical trials of efficiency are being carried out and will be reported separately.
There is no indication at present of any further increase in the degree of penicillin resistance in the gonococcal strains isolated in the current series compared with the 1966 survey.

\section{Summary}

During 1968 a further study of gonococci isolated from 97 men with gonorrhoea revealed a similar incidence of penicillin resistant strains, namely $35 \cdot 1$ per cent. in this 1968 series compared with 37.3 per cent. in 1966.

Increasing the dose of procaine penicillin from 600,000 units to 2.5 mega units resulted in a sharp fall in post-treatment gonorrhoea; the percentage of patients classified as relapsing after this large dose (6.2 per cent.) was half that in the series reported in 1966.

Even so it is suggested that there is a need for an alternative, simple and effective treatment for gonorrhoea as long as one-third or more of strains of gonococci remain relatively resistant to penicillin.

\section{References}

Evans, A. J. (1966) Brit. J. vener. Dis., 42, 251

LETCHNER, and NiCOL, C. S. (1961) Ibid., 37, 158

Nicol, C. S., Ridley, M., and Symonds, M. A. E. (1968) Ibid., 44, 315

\section{Nouvelles études sur les gonocoques resistant à la penicilline}

\section{SOMMAIRE}

En 1968, une nouvelle étude sur les gonocoques isolés chez 97 hommes atteints de gonococcie, montra une incidence équivalente de souches pénicillino-résistantes $(35,1 \%$ de la série de 1968 et $37,3 \%$ de celle de 1966).

L'augmentation de la dose pénicilline-procaïne de 600.000 U. à 2,5 méga unités entraîna une chute brutale des gonococcies post-thérapeutiques. Le pourcentage des malades considérés comme ayant rechuté après cette forte dose fut la moitié de celui de la série de 1966.

On considère cependant qu'il faut disposer d'un traitement de rechange, simple et efficace, pour cette maladie, tant qu'un tiers ou plus des souches de gonococques reste résistant à la pénicilline.

TABLE II I Minimal inhibitory concentrations of benzyl penicillin for 97 strains of gonooccci

\begin{tabular}{|c|c|c|c|c|c|c|c|c|c|c|}
\hline \multirow{2}{*}{$\begin{array}{l}\text { Presumed result of } \\
\text { treatment }\end{array}$} & \multirow{2}{*}{ Source of strains } & \multirow{2}{*}{$\begin{array}{l}\text { No. of } \\
\text { strains }\end{array}$} & \multicolumn{7}{|c|}{ No. of strains inhibited by penicillin ( $\mu \mathrm{g} . \mathrm{ml})}$. & \multirow{2}{*}{$\begin{array}{l}\text { Percentage of strains } \\
\text { relatively resistant } \\
(M I C s 0.1-0.5 \mu \mathrm{g} . / \mathrm{ml} .)\end{array}$} \\
\hline & & & 0.005 & 0.01 & 0.025 & 0.05 & $0 \cdot 1$ & $0 \cdot 25$ & 0.5 & \\
\hline \multirow[t]{2}{*}{ Failure } & Relapses & 6 & 1 & - & - & 1 & 2 & 1 & 1 & $66 \cdot 7$ \\
\hline & Re-infections & 6 & 2 & - & 一 & - & 3 & 1 & - & $66 \cdot 7$ \\
\hline \multirow[t]{3}{*}{ Success } & $\begin{array}{l}\text { Followed for } 2 \text { weeks } \\
\quad \text { or more }\end{array}$ & 44 & 21 & 4 & 1 & 1 & 8 & 7 & 2 & $36 \cdot 4$ \\
\hline & $\begin{array}{l}\text { Followed for less than } \\
2 \text { weeks }\end{array}$ & 33 & 20 & 4 & 1 & 1 & 4 & 2 & 1 & $21 \cdot 2$ \\
\hline & No assessment & 8 & 3 & 2 & - & 1 & 1 & 1 & - & $25 \cdot 0$ \\
\hline Total strains & & 97 & 47 & 10 & 2 & 4 & 18 & 12 & 4 & $35 \cdot 1$ \\
\hline
\end{tabular}

